\title{
Resolving the Unique Situation: Consequences for Identity and Psychological Well-Being
}

\author{
LAURA FRENCH BOURGEOIS \\ Université de Montréal
}

\begin{abstract}
La grossesse à l'adolescence amène généralement de nombreux changements dans la vie de la jeune mère. Le problème le plus saillant chez les mères adolescentes, par example, est le manque d'un réseau de soutien. Dans un premier temps, nous tentons d'expliquer comment peu de soutien communautaire peut mener à de bas niveaux de bien-être, et, dans un deuxième temps, nous suggérons des solutions pour pallier ce problème. Nous proposons que les jeunes mères perçoivent leur situation comme étant une situation unique. Nous stipulons que la perception de vivre une situation unique amène les jeunes mères à comparer leur situation présente à celle d'avant leur grossesse, ceci ayant comme conséquence de réduire leur bien-être. Le présent travail théorise que c'est en partageant sa situation unique avec d'autres individus dans la même situation que les comparaisons sociales deviendront disponibles et conséquemment, que le bien-être augmentera.
\end{abstract}

Mots-clés : grossesse à l'adolescence, comparaisons sociales, comparaisons temporelles, situation unique

\begin{abstract}
Teen pregnancy regularly brings about numerous changes in the life of the young mother. The most salient problem for teenage mothers, for example, is the lack of a supportive community. First, we will attempt to explain how little support from a community can lead to low levels of well-being. Secondly, we suggest solutions to overcome this problem. We propose that the young mothers perceive their situation as a Unique Situation. We advance the idea that the perception of living through a Unique Situation brings the young mothers to compare their situation to the one before their pregnancy, resulting in a decrease in well-being. This paper theorizes that by sharing a Unique Situation with others living through a similar situation, social comparisons will become available and consequently higher levels of well-being will be experienced.
\end{abstract}

Keywords: teen pregnancy, social comparisons, temporal comparisons, unique situation

$\rrbracket_{\text {Adolescent pregnancy is a worldwide phenomenon }}$ that has strong consequences for those implicated. In fact, according to a World Health Organization [WHO] report in 2009, it is estimated that 16 million young women worldwide, between the ages of 15 and 19, give birth each year, representing $11 \%$ of the yearly births (WHO, 2009). The proportion of children born to adolescent mothers can vary as much as $2 \%$ in China to $18 \%$ in Latin America. Although large disparities can

Laura French Bourgeois, Département de psychologie, Université de Montréal. Je tiens à remercier Melissa Stawski ainsi que les évaluateurs et éditeurs pour leurs commentaires constructifs tout au long du processus de révision. Je remercie également Roxane de la Sablonnière pour le support continu durant la rédaction de cet article. Toute correspondance concernant cet article doit être adressé à Laura French Bourgeois, Université de Montréal (courriel: laura.french.bourgeois@umontreal.ca. be observed between poor countries and wealthier ones, teen pregnancy is present throughout the globe.

In Canada, for example, 25000 children are born to adolescent mothers each year, which accounts for $11 \%$ of its total number of births. In Quebec, one in twelve girls will become pregnant before the age of 18 and one in four before the age of 20. In fact, it is reported that there are 3000 new births a year from young women under the age of 20 years old in this province (Rochon, 1997).

Most pregnancies among teenagers come unexpectedly, in fact only one third are planned. However, $90 \%$ of the young mothers decide to keep their child (The American Congress of Obstetricians and Gynecologists, 2008). This overwhelming number of new mothers each year brings about a trying readjustment period. In fact, teen pregnancy brings about many trying consequences that accompany the 


\section{FRENCH BOURGEOIS}

young families. In Quebec, teen pregnancy is the main cause for high school dropouts among girls. It is reported that as much as $50 \%$ to $67 \%$ of the girls who drop out of high school do so due to their pregnancy. This predisposes them to obtain unstable jobs, which often leads them to demand social welfare. According to a recent study conducted in Quebec, in the first year following their pregnancy, $50 \%$ of young mothers received welfare assistance and within the following five years, $77 \%$ of them received such financial support (Rodriguez, 2003). This is often due to the fact that they receive little assistance from their surroundings therefore making it difficult to pursue studies or to improve their situation. Furthermore, after some time, the young mothers are often left to raise their child alone as their partner has deserted them (The American Congress of Obstetricians and Gynecologists, 2008). These circumstances often bring about feelings of solitude and of rejection for the majority of young mothers. Additionally, many lose confidence in the people that surround them and wish to take on all responsibilities by themselves (Chase, Maxwell, Knight, \& Aggleton, 2006).

As well as the social problems that can emerge from motherhood at a young age, developmental drawbacks might occur. It is important to keep in mind that teen mothers are in fact adolescents who have not yet completed important developmental tasks. In fact, according to Erikson's Stages of Psychosocial Development, individuals between the ages of 12 and 18 years old are in the midst of developing their identity and are increasingly aware of how they appear to others (Cloutier \& Drapeau, 2008). It is during this stage that adolescents normally spend a significant amount of time with their peers in order to investigate different roles that they can take on during their adult life. This developmental stage is significantly more challenging for the young mothers, as they must also determine their new role as mothers. Not being able to complete a stage adequately may result in loopholes in the mother's personal development and may have negative consequences on her behavior around her child. In fact, the urge to participate in social activities may take over the sense of responsibility that she has for her child.

As illustrated, the switch from adolescence to motherhood brings about many rapid changes that can be challenging for the new mothers both on their wellbeing and on the development of their identity. For example, having many new responsibilities and often times having to accomplish them alone may impact their well-being. Additionally, not being able to take part in important developmental tasks relating to identity may have strong consequences on the way the mothers perceive their identity. The theory of the Unique Situation brings forth the idea that in times where changes are rapid and dramatic in one's life, social comparisons are pushed aside to be replaced by temporal comparisons (de la Sablonnière, Hénault, \& Huberdeau, 2009). Social comparisons are when people compare their personal situation to the one of others (Festinger, 1954), whilst temporal comparisons are when an individual compares his present situation to the one at another point in time (Albert, 1977). Research on the Unique Situation confirms that, in situations of dramatic and rapid changes, temporal comparisons lead to lower levels of well-being. The general goal of the present paper is to apply the concept of the Unique Situation to the one of teen pregnancy and to propose a model that aims at resolving the troubles instigated by being in such a situation.

\section{Explaining the Theory of the Unique Situation}

The Unique Situation can be defined as "a situation where an individual does not perceive any effective social cues in order to compare himself with other individuals or groups in a situation of change" (free translation, de la Sablonnière, Hénault, \& Huberdeau, 2009 , p. 8). This theory pursues the idea that when a Unique Situation comes about, the individual must turn to temporal comparisons since no social cues can be perceived. The use of temporal comparisons, in circumstances similar to those of the Unique Situation, will then produce lower levels of well-being. This is in line with what certain author's have found, notably that the self cannot exist without being defined with respect to others (Taylor, 1997, 2002; Tesser, 2003).

This need for social comparisons goes well beyond the Identity Stage of Erikson's Stages of Psychosocial Development as it has been found that individuals have a fundamental need to compare themselves to others (Taylor, 1997, 2002). In fact, Festinger (1954), in his Social Comparison Theory, proposed that individuals have a profound need to assess their opinions and their abilities with those of others. Later studies elaborated this point and demonstrated that social comparisons are applicable to many other areas of people's lives. For example, it was shown that social comparisons are also 


\section{RESOLVING THE UNIQUE SITUATION}

applicable to one's health condition, social life, salary and appearances (Crosby, 1976; Wheeler \& Miyake, 1992; Wills, 1981; Wood, 1989, 1996). Some studies have even found that social comparisons are present in the self-evaluation process (Beauvois, 1990; Huguet \& Monteil, 1996).

In addition to social comparisons, individuals are also prone to make temporal comparisons (Albert, 1977). More specifically, the idea behind temporal comparisons is that people compare their present situation to the one they had at another point in time. A key concept of this theory is that temporal comparisons allow individuals to maintain a sense of continuity through time with their identity. This therefore gives us the opportunity to adjust to change and to evaluate our new situation. Following studies on temporal comparisons have shown that, if one's present situation does not live up to the one of the past, a feeling of threat might be felt by the person who does such comparisons (de la Sablonnière \& Tougas, 2008).

Well-being can be affected by both temporal and social comparisons. Favorable comparisons can increase well-being the same way that unfavorable comparisons can decrease well-being. It has been demonstrated that different occasions call for different types of comparisons. According to Suls and Mullen's Life's Span Model (1982), for example, people use different types of comparisons depending on which period of their lives they are undergoing. Social comparisons are favored for most situations in life, but temporal comparisons are used during periods that are marked by rapid changes. Hence, according to this model, social comparisons take precedence over temporal comparisons, but temporal comparisons are used when rapid changes are experienced.

The Unique Situation has been able to support the idea that social comparisons have a more positive influence on self-esteem, a measure of well-being, than do temporal comparisons when periods of dramatic and rapid changes occur (de la Sablonnière et al., 2009). When no social comparisions were available and individuals were forced to turn to temporal comparisons a negative impact of self-esteem was found.

Similarly to what was observed with the Unique Situation, a recent study focusing on teenage mothers found that well-being can be increased when social comparisons are made available (Valaitis \& Sword, 2005). In this study, young mothers who felt isolated were asked to share their feeling and problems over the Internet. This study demonstrates that even though the mothers did not have face-to-face contact, most reported feeling better after sharing their experiences. In line with these results, more studies have demonstrated the strong benefits of having a group to fall onto for support when the need arises (Gable, Reis, Impett, \& Asher, 2004; Kafetsios \& Sideridis, 2006). It was also found that larger groups brought higher satisfaction levels in terms of the received support (Kafetsios \& Sideridis, 2006).

The first goal of the present paper is to explain how young mothers, similarly to the Unique Situation, lose their social cues and are therefore forced to resort to temporal comparisons. The second goal is to develop a tool to enrich the mothers' well-being in order to prevent the numerous social problems that are related to teen pregnancy. In fact, it is proposed that by sharing experiences with people in a similar situation, one can increase one's well-being. This can be explained by the return of perceivable social cues. Hence, with the new appearance of social cues, people will be enticed to switch back to social comparisons to fulfill their fundamental need.

\section{Critique of the literature}

Although the studies presented above bring forth many important contributions to the study of the relationship between group membership and wellbeing, certain questions are still left unanswered. While the positive influences of having a group to share similar experiences with has been shown (Kafetsios \& Sideridis, 2006; Valaitis \& Sword, 2005), these studies do not explain the psychological process behind this. Though the Unique Situation answers the question, it does not bring forth any solutions to resolve the problems that result from it. Therefore, even though all these studies are complimentary (the Unique Situation explaining the process by which someone's well-being is affected by rapid events, and the remaining studies emphasizing the importance of sharing ones situation to increase well-being) no link has been made between the two. The present model proposes to come full circle on the subject of the Unique Situation by suggesting solutions to resolve it and therefore bringing answers to the problems of well-being and identity. 


\section{FRENCH BOURGEOIS}

\section{Theoretical Model}

Three important elements become salient from our review of literature when the problem of teen pregnancy is considered. First, between the ages of 12 and 18, individuals are in the midst of developing their identity and peers take great importance during this period. Second, temporal comparisons take precedence in situations where social comparisons are not available (Unique Situation). Thirdly, social comparisons are more essential than temporal comparisons to assess the self and predict well-being.

The present model proposes to look at teen pregnancy as a Unique Situation. In fact, it is hypothesized that many teen mothers live through a situation that is marked by rapid changes where little or no social cues are available. This can be explained by the fact that normally, teen mothers are the only ones in their social environment to be in such a situation and that the changes are occurring rapidly. Furthermore, the fact that their partners often desert them reinforces the idea that they are very much on their own. Important school dropout rates and reliance on social welfare furthers their isolation. In fact, Chase et al. (2006) studied the factors that influence teenagers to become pregnant and the difficulties that follow the decision of keeping the child. It was found that many factors directly linked to identity and well-being were jeopardized in many of the young girls' lives such as poor family relationships, poor self-esteem and little education on romantic relationships. These circumstances often leave the young mothers to solely rely on themselves and consequently a feeling of solitude prevails. The results of this research reveal that most young mothers are alone and have a great need for a community with which they can communicate.

As we have seen in the literature review, a Unique Situation inevitably brings about temporal comparisons since no pertinent social cues are available. In the case of teen mothers, temporal comparisons would be centered on their pregnancy and their new life as mothers. Comparisons contrasting their life prior to their pregnancy to the one following their pregnancy are likely to occur. Temporal comparisons in a Unique Situation, as illustrated above, bring about less wellbeing than do social comparisons. We believe that this is even more important in the case of teenage mothers since social cues are their primary concern at this developmental stage. In fact, when developing their identity they have the fundamental need to asses and compare "who they are" in respect to peers of their age. It is predicted that this factor combined with the idea that they are forced to resort to temporal comparisons to evaluate themselves has detrimental effects on their well-being.

Although the idea of the Unique Situation is a recent one and no solutions have been put forth in order to remedy the negative impacts of this situation, a simple solution can be put in place. It is proposed that bringing social comparisons back in play will have a significant influence on the well-being of the teen mothers. Social comparisons will help the mothers not only to develop their identity properly, which would undoubtedly lead to less shortcomings in their development, but also to have pertinent social cues in order to do day to day comparisons.

The present model therefore proposes that it is essential for people living in a Unique Situation to create a support group that is composed of people that are living through a similar situation. This will allow them to form a bond with others, which will create a sense of belonging and community. They will be able to use these social cues to form their identities as mothers and as individuals.

Furthermore, when this sense of belonging is present among the members of the group, social comparisons will then become, once again, available. Individuals will be able to compare themselves with people of their community and social comparisons will replace the temporal comparisons. It is predicted that well-being will then increase since the available social comparisons will fulfill a need that could not be filled previously. Hence, returning to social comparisons will increase well-being among group members.

Higher well-being for teenage mothers can have multiple benefits. Higher well-being will give these young girls the tools to overcome countless obstacles that have come their way. With higher well-being the young mothers will have more courage to finish their studies, find jobs and secure a future for their children. In fact, the young mothers will be able to find the tools to attain their goals. 


\section{RESOLVING THE UNIQUE SITUATION}

\section{Futur Orientations}

In this article we have hypothesized a model that would resolve the setbacks brought forth by circumstances similar to a Unique Situation. As mentioned, the Unique Situation explains why people who have no social cues available are obliged to resort to temporal comparisons. It has been put forth that when social comparisons are available to the person living through a Unique Situation, the problems associated with temporal comparisons will be attenuated. The Unique Situation has been applied to teenage pregnancy. However the Unique Situation may be applied to many different circumstances such as grief or a life threatening illness.

However, to know the real value of the proposed model it is essential that it be verified empirically. The need for social comparisons is probably not the only element that affects the well-being of people living through a Unique Situation. Also, even if social comparisons are available, will people return to them as soon as they are available? It is possible that when living through a Unique Situation, the people affected will take longer to resort back to social comparisons since they have already assessed their situation with temporal comparisons.

An interesting avenue for further research would be to study individuals that have lived through positive Unique Situations such as winning the lottery or getting accepted into a prestigious program at an Ivy League school. Do they deem their situation just as positive even though they cannot compare themselves to anyone else? Is their well-being affected by the fact that they do not have any social cues? Does the rapidity of the change impact them in any way? Would their wellbeing increase if they did in fact have the possibility of making social comparisons? More research on the Unique Situation can bring answers to these questions and many more.

\section{References}

Albert, S. (1977). Temporal Comparison Theory. Psychological Review, 84, 485-503.

Beauvois, J.-L. (1990). L'acceptabilité sociale et la connaissance évaluative. Connexions, 56, 7-16.
Brown, R., \& Middendorf, J. (1996). The underestimated role of temporal comparison: A test of the life-span model. Journal of Social Psychology, 136, 325-331.

Chase, E., Maxwell, C., Knight, A., \& Aggleton P. (2006). Pregnancy and parenthood young people in and leaving care: What are the influencing factors, and what makes a difference in providing support? Journal of Adolescence, 29, 437-451.

Cloutier, R., \& Drapeau, S. (2008). Psychologie de l'adolescence. Montréal: G. Morin.

Crosby, F. (1976). A model of egoistical relative deprivation. Psychological Review, 83, 85-113.

de la Sablonnière, R., Hénault, A.-M., \& Huberdeau M.-E. (2009). Social and temporal comparisons: The sequential approach and the role of the unique situation. Cahiers Internationaux de Psychologie Sociale, 83, 3-24.

de la Sablonnière, R., \& Tougas, F. (2008). Relative deprivation and social identity in times of dramatic social changes: The case of nurses. Journal of Applied Social Psychology, 38, 2293-2314.

Festinger, L. (1954). A theory of social comparison processes. Human Relations, 7, 117-140.

Gables, S., Reis, H., Impett, E., \& Asher, E. (2004). What do you do when things go right? The intrapersonal and interpersonal benefits of sharing positive events. Journal of Personality and Social Psychology, 87, 228-248.

Huguet, P., \& Monteil, J. M. (1996). Comparaison sociale, genre et performances cognitives. Dans J. L. Beauvois, R. V. Joule, \& J. M. Monteil (Éds), Perspectives cognitives et conduites sociales, (pp. 33-48). Neuchâtel, Paris: Delachaux et Niestlé.

Kafetsios, K., \& Sideridis, G. (2006). Attachement, social support and well-being in young and older adults. Journal of Health Psychology, 11, 863-876.

Lajoie, M. (2003). Prévenir la grossesse à l'adolescence, Prévention en Pratique Médicale. Montreal, Québec : Direction de la Santé Publique.

Rochon, M. (1997). Taux de grossesse à l'adolescence. Québec, 1980 à 1993, Régions sociosanitaires de résidence, 1993-1995 et autres groupes d'âge. Québec, Québec: Ministère de la Santé et des Services sociaux.

Rodriguez, J. (2003). La contraception d'urgence. Paediatrics \& Child Health, 8, 189-192.

Suls, J., \& Mullen, B. (1982). From the cradle to the grave: Comparison and self-evaluation across the life-span. Dans J. Suls (Éd.), Psychological perspectives on the self (pp. 97-125). Hillsdale, NJ: Erlbaum. 
Taylor, D. M. (1997). The quest for collective identity: The plight of disadvantaged ethnic minorities. Canadian Psychology, 38, 174-189.

Taylor, D. M. (2002). The quest for identity: From ethnic minorities to generation Xers. New York, NY. Praeger Publications.

Tesser, A. (2003). Self-evaluation. Dans M. R. Leary, \& J. P. Tangney (Éds.), Handbook of self and identity (pp. 275-289). New York, NY : Guilford Press.

The American Congress of Obstetricians and Gynecologists (2008, May 1). Rise in Births to Teens Worrisome-ACOG Encourages Support of the National Day to Prevent Teen Pregnancy. [Press release] Washington, DC.

Valaitis, R., \& Sword, W. (2005). Online discussion with pregnant and parenting adolescents: Perspectives and possibilities. Health Promotion Practice, 6, 464-471.

Wheeler, L., \& Mikaye, K. (1992). Social comparison in everyday life. Journal of Personality and Social Psychology, 62, 760-773.

Wills, T. A. (1981). Downward comparison principles in social psychology. Psychological Bulletin, 90, 245-271.

Wilson, A., \& Ross, M. (2000). The frequency of temporal-self and social comparisons in people's personal appraisals. Journal of Personality and Social Psychology, 78, 928-942.

Wood, J. V. (1989). Theory and research concerning social comparisons of personal attributes. Psychological Bulletin, 22, 520-537.

Wood, J. V. (1996). What is social comparison and how should we study it? Personality and Social Psychology Bulletin, 49, 1169-1183.

World Health Organization (2009). Adolescent pregnancy: A culturally complex issue, Récupéré de http://www.who.int/bulletin/volumes/87/6/09-02060 9/fr/index.html.

Reçu le 12 août 2009

Révision reçue le 22 janvier 2010 Accepté le 15 février 2010 